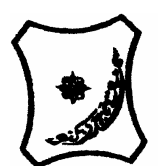

Bayero Journal of Pure and Applied Sciences, 7(2): 164 - 168

Received: September 2014

Accepted: December 2014

ISSN $2006-6996$

\title{
PALYNOMORPHS AND FLORAL BLOOM AS TAXONOMIC CHARACTERS IN SOME SPECIES OF THE GENUS AMARANTHUSL. (AMARANTHACEAE)
}

\author{
Zhigila, D. A. ${ }^{1}$; Yuguda, U. A. ${ }^{1}$ Akawu, J. J. ${ }^{1}$ and Oladele, F.A. ${ }^{2}$ \\ ${ }^{1}$ Botany Programme, Department of Biological Sciences, Gombe State University, Gombe, Gombe State, Nigeria \\ ${ }^{2}$ Applied Plant Anatomy and Wood Technology Laboratory, Department Of Plant Biology, University Of Ilorin, \\ Ilorin, Nigeria \\ *Correspondence author: dandrawus@ymail.com
}

\begin{abstract}
Fresh flowers of five species of Amaranthus were studied and documented in detail using light microscope to examine their morphology and pollen characteristics in relation to taxonomy. These species include Amaranthus spinosus, A. viridis, A. hybridus, A. australis and A. tricolor. The species showed close relationship in their pollen surface characteristics with some slight variations in psilate, micropitted or microrugulate ornamentations. The microscopic study of the pollens revealed the presence of 5 types of pollen apertures which include dicolpate, monolete, Inaperaturate, periporate and triporate. The analysis of mean polar and equatorial measurement i.e. the pollen sizes showed that the largest pollen was recorded in A. hybridus $(61.95 \pm 2.40 \mu m)$ and the smallest pollen was recorded in A. spinosus $(23.70 \pm 0.65 \mu \mathrm{m})$. The mean density of pollens was found to be highest in $A$. australis $\left(12.55 \pm 1.13 \mathrm{~mm}^{2}\right)$ and the lowest mean density was recorded in A. hybridus $\left(1.29 \pm 0.05 \mathrm{~mm}^{2}\right)$. Two diagnostic shapes were noticed in the samples studied, these are - spherical grains in A. spinosus and A. viridis and oval grains in A. hybridus, A. australis and $A$. tricolor. The study revealed that floral and palynological characters are of taxonomic significance in the genus.

Keywords: Pollen morphology, flower, taxonomy, Amaranthus,
\end{abstract}

INTRODUCTION

The genus Amaranthus L. consists of about 70 species, of which 40 are native to the Americas and the rest to Australia, Africa, Asia and Europe (Sauer, 1955 and Costea et al., 2011). It is an important genus of weeds and edible vegetables (Olorode, 1984), dicotyledonous, herbaceous plants with erect stems and enormous inflorescences. The flowers are arranged in small and much contracted cymes, the first flower within each cyme, in monoecious species being male (Costea et al., 2011). Exceptions to this are $A$. dubius and $A$. spinosus which have the male and female flowers on separate cyme (Murray, 1940). Due to some stated unique properties and versatile usage, grain amaranth has gained increased attention since 1970s. This re-discovered crop has some agricultural advantages and noted ability to grow successfully in adverse environmental conditions such as high irradiance, temperature and drought. It is one of a few C4 dicots belonging to the group of NADmalic enzyme-type of C4 metabolism. Amaranthus is a plant which is known to have some ethnopharmacological activities (Khan et al., 2011) with a high nutritional value and its flowers produce edible seeds (Mayhew and Penny, 1998). Since Amaranthus species have a wide array of uses, there is need to encourage their cultivation for domestic and industrial uses (AbdulRaham and Oladele, 2004).

In recent treatment of Amaranths, only two or three infrageneric taxa were recognised usually sections Amaranthus and Blitopsis (Carretero, 1985; Mosyakin and Robertson, 1996). However, such a complicated taxon requires a more detailed study. A complete system of the genus can be worked out only as part of the taxonomic revision at species level on a worldwide basis, because proper placement of many taxa especially those native to South America, Australia and Africa is not completely clear yet.

Pandey and Misra (2009) and Zhigila et al. (2014), suggested that pollen morphological characters play a major role in solving taxonomic problems. Palynological characters have been able to reposition several disputed genera and interpret problems related to the origin and evolution of many taxa (Nair, 1980) and provide classification of angiosperms (Cronquist, 1981). Quantitative and qualitative analysis of pollen assemblages, on the other hand, provides the primary basis for interpretation of plant community response to climatic and anthropogenic environmental change (Kneller and Peteet, 1999; Watts, 1979; Davis, 1969; Willard et al., 2003, 2004). Zhigila et al. (2014) suggested that such analyses rely on accurate identification of pollens for quantitative and qualitative comparison. Hence pollen spore morphology helps in delimitation of plant taxa. The present study therefore is to elucidate use of the variation in floral and pollen features for species delimitation in some Amaranths.

\section{MATERIALS AND METHODS}

Study materials

Flowers of five species of genus Amaranthus were collected for palynological studies (Table 1). 
The specimens encountered were identified to species level using the services of experts and employing relevant flora books such as Handbook of West African Weeds (Okezie and Agyakwa, 1998), Hausa names for plants and trees (Blench and Dendo, 2007) and authenticated at the Herbarium in the Department of Plant Biology, University of Ilorin, Ilorin, Nigeria.

\section{Pollen isolation and microscopic studies}

Pollens were placed and smeared on microscope slides and immersed in a few drops of isopropyl alcohol for 5 minutes to remove waxy substance from the pollens. The specimens were then mounted in glycerine for microscopic observation. The cover slips were ringed with nail varnish to create a semi-permanent slide. This method followed those of Horrocks et al. (1999) as amended by AbdulRahaman et al. (2013). Specimens were photographed under oil immersion using Am scope microscopic camera (MU1000, FMA050) and Kodak digital camera (Kodak Easy Share C913). Measurements were made using an ocular micrometer, pollen description and identifications followed those of Willard et al. (2004).

Frequency of pollen types: Using 35 fields of view at $\times 40$ objective as quadrat, the numbers of pores on pollens were noted to determine the frequency of the different pollen types present. Frequency of each pollen type was expressed as percentage occurrence of such pollen types based on all occurrences using this formula: $P / y \times 100$ where $p=$ the occurrence of each pollen type in the field of view; $y=$ total occurrences of all pollen types.

Density of pollen types: The density of pollen types was determined as the number of pollen types per square millimetre $\left(\mathrm{mm}^{2}\right)$. Fields of view at $\mathrm{x} 40$ objective in a square millimetre were used for the counting.

Statistical analysis: All data were processed using Analysis of Variance (ANOVA) and Duncan's Multiple Range Test (DMRT). Computer software used was SPSS version 17 . A probability value of 0.05 was used as benchmark for significant difference between parameters.

\section{RESULTS AND DISCUSSION}

Pollen variations mainly in the pollen types, sizes, shapes and ornamentations were observed. Five types of pollen apertures were identified from all the five species studied (Table 3 and Plates 1 - 9) with periporate and monolete being the most frequent occurring $100 \%$ in $A$. australis and $78 \%$ in $A$. spinosus respectively (Table 3 ). Periporate occurred in $A$. australis and $A$. hybridus, inaperaturate occurred in $A$. viridis, $A$. hybridus and $A$. australis. Monolete occurred in $A$. spinosus and $A$. viridis. Triporate occurred only in $A$. tricolor. An example of the role of pollen grains in delimitation of taxa is Nelumbo whose separation from Nymphaeaceae into distinct family Nelumbonaceae is largely supported by tricolpate pollens of Nelumbo as against the monocolpate pollens in Nymphaeaceae (Pandey and Misra, 2009). Pollen grains in the genus Amaranthus are spheroidal and have between 30-65 pores in pigweed (Website, 1). The pollen ornamentations are mostly psilate followed by micropitted and microrugulate. It was observed that $A$. spinosus had two types of pollen ornamentation (microrugulate and psilate) with psilate recorded higher frequency $(78.43 \%), A$. hybridus was observed to have psilate and micropitted and micropitted recorded higher frequency (74.40\%). $A$. viridis and $A$. tricolor have psilate ornamentation while $A$. australis was observed to have micropitted ornamentation (100\%). In the analysis of mean polar and equatorial measurement i.e. the pollen sizes (Table 3), it showed that the largest pollen was recorded in $A$. hybridus $(61.95 \mu \mathrm{m})$ and the smallest pollen was recorded in $A$. spinosus $(23.70 \mu \mathrm{m})$. The density of pollens was found to be highest in $A$. tricolor $\left(10.25 / \mathrm{mm}^{2}\right)$ and the lowest density was recorded in $A$. hybridus $\left(1.29 / \mathrm{mm}^{2}\right)$. Two diagnostic shapes were noticed in the samples studied (Plates 1 9). These are - spherical grains in $A$. spinosus and $A$. viridis (Plates 1 and 5 ) and oval grains in A. hybridus, $A$. australis and $A$. tricolor (Plates 2, 3, 4, 6, 7, 8 and 9). Franssen et al. (2001) observed that the pollen grains in species of Amaranthus were spherical shaped with polypantoporate, or golf ball-like, aperture arrangement. Variations in pollen morphology may provide taxonomic and evolutionary significance in identification, differentiation and classification of taxa (Pandey and Misra, 2009). The physical properties of amaranth pollen, specifically size, density, and settling velocity, can influence pollen flight and pollinosis (Sosnoskie et al., 2009).

Results of this study provide evidence that Amaranthus species are eurypalynous (multipalynous) and that the genus is anemophilous. The pollen grains are generally small, rounded, smooth, thin-walled and dry but vary among species within this genus. This indicates that pollen characteristics may be used to delimit the species in this genus. Based on the features observed above, the following indented dichotomous key has been developed to allow for separation of the five species of Amaranthus studied

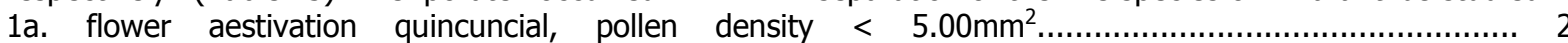

2a. Flower type spike, flower colour green or red, inaperaturate pollen aperture present...................3

3a. Pollen ornamentation psilate, pollen aperture monolete present................. . viridis

3b. Pollen ornamentation micropitted and psilate, pollen aperture periporate

Present. A. hybridus 2b. Flower type cyme, flower colour green, dicolpate pollen aperture present........ A. spinosus

1b. Flower aestivation imbricate, pollen density $>5.00 \mathrm{~mm}^{2}$

4a. Pollen aperture periporate, pollen ornamentation micropitted.................. australis

4b. Pollen aperture triporate present, pollen ornamentation psilate.

A. tricolour 
Table 1: Plant Collection Information

\begin{tabular}{|c|c|c|c|}
\hline Scientific name & Common name & Local name & $\begin{array}{l}\text { Date of collection } \\
\mathrm{DD} / \mathrm{mm} / \mathrm{yy}\end{array}$ \\
\hline A. spinosus L. & Wild spinach & $\begin{array}{l}\text { Tete elegun (Yoruba), Namijin zaki } \\
\text { banza (Hausa); inine ogwu(Igbo) }\end{array}$ & $13 / 06 / 2013$ \\
\hline A. hybridus L. & Green amaranth & $\begin{array}{l}\text { Tete, Olorungbin (Yoruba); aleho } \\
\text { (Hausa) }\end{array}$ & $21 / 06 / 2013$ \\
\hline A. viridis $\mathrm{L}$. & slender amaranth & $\begin{array}{l}\text { Malan kotshi (Hausa); abalaye } \\
\text { (Yoruba) and atitee (Igbo) }\end{array}$ & $07 / 07 / 2013$ \\
\hline A. tricolor $\mathrm{L}$. & $\begin{array}{l}\text { Chinese spinach, Joseph's } \\
\text { coat }\end{array}$ & & $18 / 07 / 2013$ \\
\hline $\begin{array}{l}\text { A. australis (Gray) } \\
\text { Sauer }\end{array}$ & Southern amaranth & Alehon daji (Hausa) & $19 / 07 / 2013$ \\
\hline
\end{tabular}

Table 2: Some Floral Characteristics of the five Species of Amaranthus

\begin{tabular}{llll}
\hline Taxa & Flower type & Flower colour & Aestivation \\
\hline A. spinosus & cyme & Green & Quincuncial \\
A. hybridus & Spike & Green & Quincuncial \\
A. viridis & Spike & Green or red & Quincuncial \\
A. tricolor & Spike & Green or red & Imbricate \\
A. australis & spike & green & Imbricate \\
\hline
\end{tabular}

Table 3: Pollen Characterization in the Five Species of Amaranthus

\begin{tabular}{|c|c|c|c|c|c|c|}
\hline Taxa & Aperture & Ornamentation & $\begin{array}{l}\text { Pollen } \\
\text { shape }\end{array}$ & $\begin{array}{c}\text { Pollen size } \\
\left(\mu^{2}\right)\end{array}$ & $\begin{array}{c}\text { Pollen } \\
\text { Density } \\
\left(\mathbf{m m}^{2}\right) \\
\end{array}$ & $\begin{array}{c}\text { Pollen } \\
\text { Percentage } \\
(\%)\end{array}$ \\
\hline \multirow[t]{2}{*}{ A. spinosus } & Dicolpate & Microrugulate & Spherical & $52.93 \pm 1.11$ & $2.75 \pm 0.10$ & 21.57 \\
\hline & Monolete & Psilate & Spherical & $23.70 \pm 0.65$ & $10.00 \pm 0.44$ & 78.43 \\
\hline \multirow[t]{2}{*}{ A. hybridus } & Inaperaturate & Psilate & Oval & $58.21 \pm 2.12$ & $1.29 \pm 0.05$ & 25.60 \\
\hline & periporate & Micropitted & Oval & $61.95 \pm 2.4$ & $3.75 \pm 0.03$ & 74.40 \\
\hline \multirow[t]{2}{*}{ A. viridis } & monolete & Psilate & Spherical & $54.28 \pm 3.77$ & $2.40 \pm 0.06$ & 37.50 \\
\hline & inaperaturate & Psilate & Spherical & $56.36 \pm 3.34$ & $4.00 \pm 0.40$ & 62.50 \\
\hline \multirow[t]{2}{*}{ A. tricolor } & inaperaturate & Psilate & Oval & $49.66 \pm 2.2$ & $10.25 \pm 0.64$ & 54.67 \\
\hline & triporate & Psilate & Oval & $32.41 \pm 1.23$ & $8.50 \pm 0.04$ & 45.33 \\
\hline A. australis & periporate & micropitted & oval & $24.62 \pm 1.19$ & $12.55 \pm 1.13$ & 100 \\
\hline
\end{tabular}

Plate 1: Polar view of Pollen of $A$. spinosus $\mathrm{x} 400$

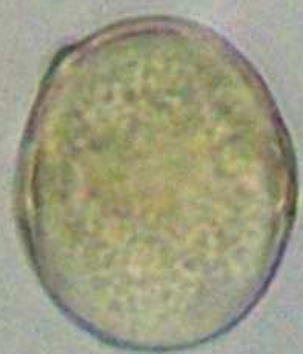

Plate: polar view of inaperaturate Pollen of $A$. hybridus $x 400$
Plate 2: polar view of monolete pollen of

A. spinosus $\times 400$

Plate 4: polar view of periporate pollen of $A$. hybridus $x 400$ 


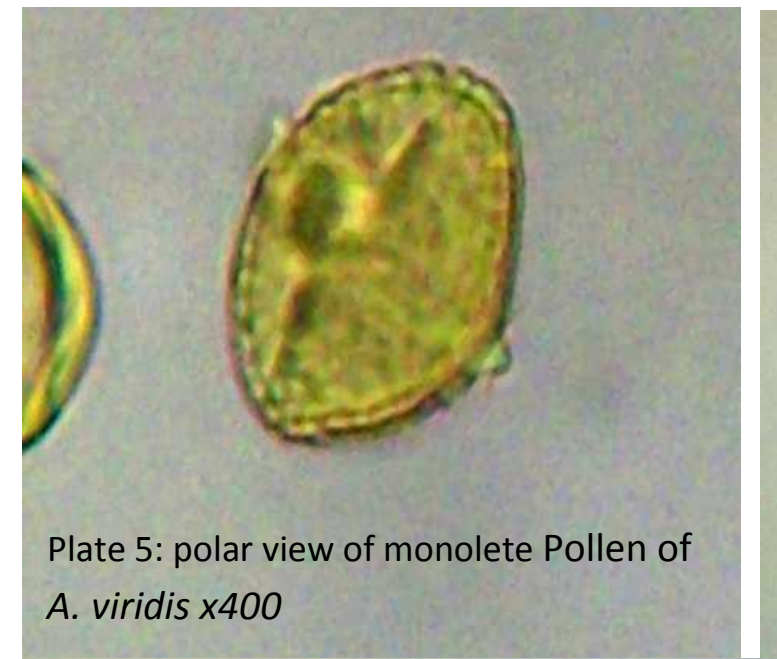

A. viridis $\times 400$

Plate 7: polar view of inaperaturate pollen of

\section{A. tricolor $\times 400$}

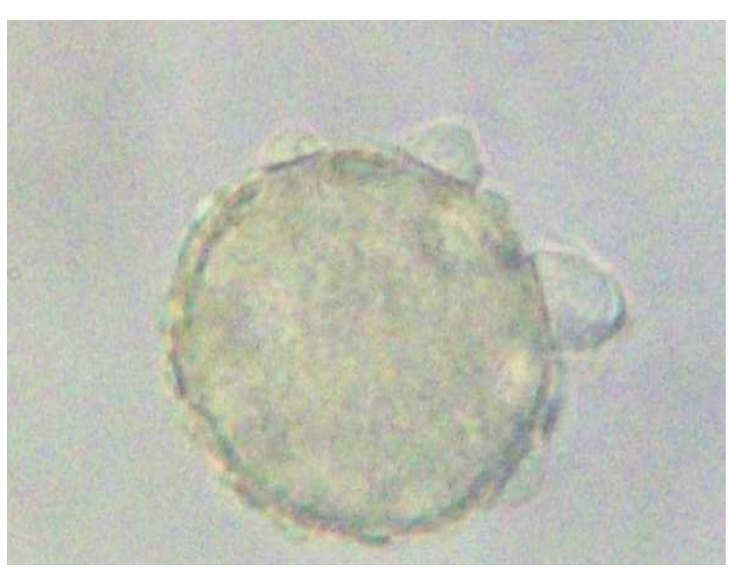

Plate 9: polar view of periporate pollen of $A$.

australis $x 400$

\section{CONCLUSION}

Two diagnostic shapes were noticed in the samples studied, these are - spherical grains in $A$. spinosus

\section{REFERENCES}

AbdulRahaman, A. A. and Oladele, F.A. (2004). Types, densities and frequencies of trichomes in some Nigerian vegetable species. Nigerian Journal Pure and Applied Sciences, 19:1653 - 1658

Abdulrahaman, A. A., Liadi, M. T., Musa, A. K., Kolawole, O. S. and Oladele, F. A. (2013).

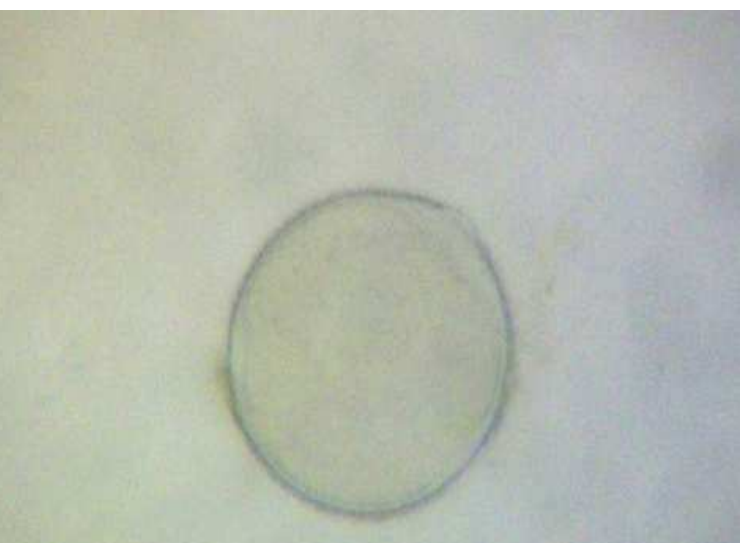

Plate 6: polar view of inaperaturate Pollen of

A. viridis $\times 400$

Plate8: polar view of triporate pollen of $A$. tricolor $x 400$

and $A$. viridis and oval grains in $A$. hybridus, $A$. australis and $A$. tricolor. The study further revealed that floral and palynological characters are of taxonomic significance in the genus.

Pollens in bee breads as indicator of honey sources. (In press).

Blench, R. and Dendo, M., (2007). Hausa Names for Plants and Trees. 8 Guest Road, Cambridge CB1 2AL, United Kingdom. 2nd Edition. Pp. 49 $-50$. 
Carretero, J. L. (1985). Consideraciones Sobre Las Amarantaceae Ibericas - anales Jard. Bot. madrid 41:271 - 286 .

Costea, M., Sanders, A., Waines, G. (2001). Preliminary Results Toward a Revision of the Amaranthus Hybridus Species Complex (Amaranthaceae). SIDA, 19(4): $931-974$

Cronquist, A. (1981). An Integrated System of Classification of Angiosperms. Columbia University Press, New York. Pp. 111 - 112.

Davis, M.B. (1969). Climatic Changes in Southern Connecticut Recorded by Pollen Deposition at Rogers Lake. Ecology, 50: 409-422

Franssen, A. S., Skinner, D.Z., Al-Khatib, K. and Horak, M.J. (2001). Pollen morphological differences in Amaranthus species and interspecific hybrids. Weed Science, 49(6):732737.

Horrocks, M., Coulson, S. A. and Walsh, K. A. J. (1999). Forensic palynology: variation in the pollen content of soil on shoe soles and shoe prints in soil. Journal of Forensic Science, 44(1): $119-122$.

Khan, M., Musharaf, S., Ibrar, M. and Farrukh, H (2011). Pharmacognostic evaluation of the Amaranthus viridis L. Research In Pharmaceutical Biotechnology, 3(1): 11-16

Kneller, M., and Peteet, D.(1999) Late-Glacial to early Holocene climate changes from a central Appalachian pollen and macrofossil record. Quaternary Research, 51: 133-147.

Mayhem, S. and Penny, A. (1998). Tropical and SubTropical Food. Macmillan Publishers. Hong Kong. Pp $80-102$.

Mosyankin, S. L. and Robertson, K.R. (1996). New Infrageneric Taxa and Combination in Amaranthus (Amaranthaceae). Annals of Botany, Fennici 33:275 - 281. ISSN 0003-3847

Murray, M.J. (1940). Cochicine induced tetraploid in dioecious and monoecious species of Amaranthaceae. J. Hered. 31:477-485

Nair, P.K.K. (1980). Pollen Morphology of Angiosperms. Vikas Publications, New Delhi. Pp. 92 -93.

Olorode, O. (1984). Taxonomy of West African Flowering Plants. Longman Group Limited. The Book Project, Obafemi Awolowo University, IleIfe, Nigeria. Pp. $11-15$

Okezie, I.A. and Agyakwa, C.W. (1998). A Handbook of West African Weeds. 2nd Edition. International Institute of Tropical Agriculture, Ibadan, Nigeria

Pandey, S.N. and Misra, S.P. (2009). Taxonomy of Angiosperms. Ane Books Pvt. Ltd. Parwana Bhawa, Darya Ganj, New Delhi, India. Pp. 285 $-292$
Sauer, J.D. (1955). Revision of the dioecious amaranths. Madrono, 13:5-46

Sosnoskie, L.M., Webster, T.M., Dales, D., G. C. Rains, G.C., Grey, T.L. and Culpepper, A.S. (2009). Pollen grain size, density, and settling velocity for palmer amaranth (Amaranthus palmeri). Weed Science (Impact Factor: 1.73), DOI:10.1614/WS-08-157.1

Website, 1. Pollenlibrary.com

Willard, D.A., Cronin, T.M., and Verardo, S. (2003). Late-Holocene climate and ecosystem history from Chesapeake Bay sediment cores, USA. The Holocene, 13: 201-214.

Willard, D.A., Cooper, S.R., Gamez, D. and Jenshen, J. (2004). Atlas of pollen and spores of the Florida everglades. Palynology, 28: 175 - 227.

Watts, W.A. (1979). Late Quaternary Vegetation of Central Appalachian and the New Jersey coastal plain. Ecological Monographs, 49: 427469.

Zhigila, D.A.; Sawa, F.B.J.; Abdul, S.D. and Danailu, G. (2014). Diversity of pollen morphology in accessions of Sesamum indicum $\mathrm{L}$. International Journal of Modern Botany, 4(1): $22-28$. 